\title{
Hepatitis B Surface Antibody Measurement
}

National Cancer Institute

\section{Source}

National Cancer Institute. Hepatitis B Surface Antibody Measurement. NCI Thesaurus.

Code C74711.

The determination of the surface antibody reaction of a sample to the Hepatitis B virus. 